\title{
KẾT QUẢ PHẪU THUẬT KẾT HỢP XƯƠNG SƯỜn GÃY BẦNG TẤM NẸP VÍT TẠI BỆNH VIỆN HŨ̉U NGH! VIỆT ĐỨC
}

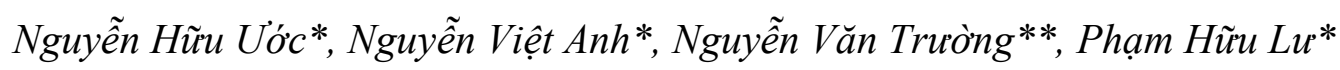

\section{TÓM TÁ́T}

Tổng quan: Gãy xương sườn là tổn thương chính trong chấn thương ngực, hầu hết chỉ điều trị bảo tồn. Trường hợp gãy nhiều xương, gãy di lệch nhiều thì có chỉ định phẫu thuật cố định xương gãy. Có nhiều kỹ thuật mổ, trong đó cố định bằng tấm nẹp vít là phổ biến nhất. Bệnh viện Hữu nghị Việt Đức đã bắt đầu ứng dụng phương pháp này từ năm 2018. Nghiên cứu nhằm đánh giá kết quả ban đầu của phương pháp.

Đối tượng phương pháp: Nghiên cứu mô tả cắt ngang tiến cứu trên các bệnh nhân chấn thương ngực phức tạp, được chỉ định và thực hiện phẫu thuật cố định ổ gãy xương sườn bằng tấm nẹp vít loại RibFixBlu, và đánh giá kết quả sớm sau mổ, từ tháng $1 / 2018$ đến tháng 3/2020.

Kết quả: Bao gồm 22 bệnh nhân, tuổi 45,3 $\pm 13,1$ (23-68), nam chiếm 68,2\%. Khá nhiều chấn thương ngực thể nặng: mảng sườn di động bên 40,9\% (9 ca), biến dạng lồng ngực 54,5\% (12 ca). Số xương sườn gãy gãy phát hiện được trên chụp CLVT là $8,86 \pm 3,53$ xương / 1 bệnh nhân $(6-19)$, cao hơn có ý nghĩa $(\mathrm{p}<0,05)$ so với phim $\mathrm{X}$ quang ngực thẳng, nhưng tương đương nhau đối với các xương sườn 4-6. Chỉ số xương sườn gãy (RFS) hầu hết đều ở mức độ 3-4. Thời gian phẫu thuật trung bình là $98,5 \pm 12,5$ phút $(82-$ 130). Số lượng xương được kết hợp trung bình là $3,1 \pm 1,03$ xương, nhiều nhất là 6 xương cho bệnh nhân bị gãy 19 xương, đa số ở cung bên xương sườn $4-7$, trong đó có $100 \%$ ở xương sườn 5 và $81,8 \%$ ở xương sườn 6 . Không có các biến chứng đáng kể nào trong khi mổ. Hiệu quả giảm đau sau mổ được thấy rõ ở hầu hết các bệnh nhân. Kết quả sớm: khỏi không có biến chứng 86,4\% (19 ca), 2 ca xẹp phổi và $1 \mathrm{ca}$ viêm phổi; thời gian nằm viện $12,2 \pm 4,9$ ngày (8-25); không có ca nào tử vong trong nhóm nghiên cứu.

Kết luận: Phẫu thuật kết hợp xương sườn gãy bằng tấm nẹp vít là phương pháp an toàn và hiệu quả. Chỉ định phẫu thuật được chọn lựa cẩn thận và đảm bảo tính hợp lý dựa trên triệu chứng lâm sàng và cận lâm sàng. Cần có nghiên cứu so sánh với nhóm điều trị bảo tồn, cũng như đánh giá hiệu quả lâu dài của phẫu thuật.

Tù khóa: cố định xuơng sươn, nẹp vít, Việt Đức

\section{SUMMARY \\ RESULTS OF THE RIB FRACTURES \\ STABILISATION BY LOCKED PLATE \\ FIXATION AT VIET DUC UNIVERSITY HOSPITAL}

Overview: Fractures of the ribs are a major lesion of chest trauma, mostly with conservative treatment. In case of multiple fractures, multiple displacement fractures, surgical fixation of the broken rib is indicated. There are many surgical techniques, of which fixing with a blocked plate is the most common. Viet Duc Hospital has started to apply this method since 2018. The study aims to evaluate the initial results of the method.

Method: A prospective cross-sectional descriptive study in patients with complex chest trauma, indicated and performed surgery to fix the rib fracture with a RibFixBlu type blocked plate, and early evaluation of the ealier results, from January 2018 to March 2020.

Results: Including 22 patients, aged $45.3 \pm$ 13.1 (23-68), male take $68.2 \%$. Quite a lot of

\footnotetext{
* Bệnh viện Hũu nghị Việt Đức, Đại học Y Hà Nội

** Bệnh viện đa khoa Xanh Pôn

Nguòi chịu trách nhiệm khoa học: Nguyễn Hũu Ước

Ngày nhận bài: 26/12/2020 - Ngày Cho Phép Đăng: 26/01/2021
} 
serious chest injuries: chest fail $40.9 \%$ (9 cases), chest deformity $54.5 \%$ (12 cases). The number of fractured ribs detected on CT scan was $8.86 \pm$ 3.53 ribs / 1 patient (6-19), which was significantly higher $(\mathrm{p}<0.05)$ than with a normal chest radiograph, but equivalent for $4^{\text {th }}-6^{\text {th }}$ ribs. The index of rib fractures (RFS) is mostly at the level of 3-4. Average surgery time is $98.5 \pm 12.5$ minutes $(82-130)$. The average number of rib fixation was $3.1 \pm 1.03$, up to 6 ribs for patients with 19 fractures, most in the lateral $4^{\text {th }}-7^{\text {th }}$ ribs, of which $100 \%$ was in the $5^{\text {th }}$ rib and $81.8 \%$ in $6^{\text {th }}$ rib. No significant complications during surgery. The postoperative analgesic effect is evident in most of the patients. Early results: $86.4 \%$ uncomplicated cure (19 cases), 2 cases of atelectasis and 1 case of pneumonia; length of stay in hospital $12.2 \pm 4.9$ days (8-25); There were no deaths in the study group.

Conclusion: Rib's fixation with a blocked plate is a safe and effective method. Surgical indications are carefully selected and reasonable based on clinical and subclinical symptoms. There is a need for comparative studies with the conservative treatment group, as well as evaluating the long-term effectiveness of surgery.

Keywords: rib fixation, blocked plate fixation, Viet Duc

\section{I. ĐẶT VẤN ĐỂ}

Gãy xương sườn là một tổn thương rất thường gặp trong chấn thương ngực kín, gây ra nhiều hậu quả khác nhau, từ nhẹ như đau ngực, hạn chế hô hấp; đến tràn máu - tràn khí màng phổi; rồi biến dạng lồng ngực và suy hô hấp nặng do mảng sườn di động. Mảng sườn là một thể bệnh đặc biệt của chấn thương ngực kín, gây ra nhiều rối loạn toàn thân, thậm chí dẫn tới tử vong. Các biến chứng cũng như tử vong do chấn thương ngực kín thường liên quan tới 3 yếu tố chính gồm: giảm thông khí do đau và biến dạng lồng ngực, giảm khả năng trao đổi khí do tổn thương phổi, và các biến chứng của thở máy [1],[2].
Đối với đa số các dạng gãy xương sườn, bảo tồn là giải pháp điều trị chủ đạo; các can thiệp ngoại khoa chủ yếu dành cho tổn thương của phổi - khoang màng phổi. Tuy nhiên, với những trường hợp chấn thương ngực kín nặng, gãy - di lệch nhiều xương sườn, điều trị bảo tồn không đủ giải quyết tốt những tổn thương nặng nề của thành ngực, gây chậm phục hồi của các thương tổn ở phổi và các cơ quan khác, làm thời gian nằm viện kéo dài với nhiều biến chứng kèm theo như viêm phổi, xẹp phổi, ổ cặn màng phổi thậm chí suy hô hấp, thở máy kéo dài và tử vong. Nếu qua được, lâu dài cũng để lại nhiều di chứng như hạn chế hô hấp, biến dạng lồng ngực, đau mạn tính...[1],[3],[4].

Kết hợp xương sườn (KHXS) là phương pháp điều trị có từ những năm 1960, đã có nhiều nghiên cứu đánh giá và so sánh về hiệu quả của KHXS trong điều trị chấn thương ngực nặng, đặc biệt trong thể bệnh mảng sườn di động; theo đó KHXS giúp giảm tỷ lệ biến chứng cũng như tử vong, giảm tình trạng đau mạn tính cũng như hạn chế hô hấp và biến dạng lồng ngực [1],[5]. Tại Việt Nam, KHXS bắt đầu được áp dụng tại bệnh viện (BV) Hữu nghị Việt Đức cho một số bệnh nhân từ cách đây 20 - 30 năm, với hiệu quả không cao do biến chứng nhiễm trùng vết mổ và chi phí vật tư quá lớn ở thời điểm đó. Vài năm gần đây, có một số dụng cụ KHXS bắt đầu du nhập vào Việt Nam, như tấm nẹp vít RibFixBlu (công ty Zimmer Biomet), và bước đầu được ứng dụng ở vài cơ sở y tế lớn, tuy nhiên chưa có báo cáo chuyên sâu nào về chủ đề này. Tại BV Việt Đức, phương pháp KHXS bằng tấm nẹp vít này bắt đầu được thực hiện thường qui từ đầu năm 2018. Để đánh giá đúng hiệu quả của phương pháp, chúng tôi tiến hành nghiên cứu "Kết quả phẫu thuật kết hợp xương sườn gãy bằng tấm nẹp vít tại bệnh viện Hữu nghị Việt Đức" nhằm mục tiêu nhận xét chỉ định và đánh giá kết quả bước đầu của phương pháp mới này. 


\section{II. ĐỐI TƯợNG VÀ PHƯớng PHÁP NGHIÊN CÚU}

Nghiên cứu mô tả cắt ngang tiến cứu trên các bệnh nhân chấn thương ngực kín, xương sườn gãy phức tạp, được thực hiện phương pháp KHXS từ tháng $1 / 2018$ đến tháng $3 / 2020$, tại Trung tâm Tim mạch và Lồng ngực, BV Hữu nghị Việt Đức; với các chỉ số nghiên cứu gồm: tuổi, giới, hoàn cảnh tai nạn, triệu chứng lâm sàng và cận lâm sàng $(X$ quang và chụp cắt lớp vi tính ngực), chỉ định KHXS, thông số phẫu thuật và hậu phẫu. Phương pháp xử lý số liệu bằng phần mềm Excel 2010 và SPSS 16.0. Phương tiện thực hiện KHXS là bộ tấm nẹp, vít các cỡ và dụng cụ kết hợp xương RibFixBlu của công ty Zimmer Biomet, nhập qua phòng Vật tư của BV Việt Đức.

Qui trình nghiên cứu: Chấn thương ngực kín + gãy xương sườn phức tạp (lâm sàng, chẩn đoán hình ảnh) $\rightarrow$ Chỉ định KHXS gãy bằng tấm nẹp vít $\rightarrow$ Phẫu thuật KHXS bằng tấm nẹp vít $\rightarrow$ Săn sóc hậu phẫu tới khi ra viện.

Đạo đức nghiên cứu: chỉ định và qui trình phẫu thuật được thông qua Hội đồng khoa học của BV Việt Đức, được Bảo hiểm y tế chấp nhận thanh toán vật tư theo qui định, và được lãnh đạo Trung tâm tim mạch và lồng ngực trực tiếp chỉ đạo. Bệnh nhân và gia đình được giải thích kỹ về mọi bước của nghiên cứu và ký cam kết thực hiện phẫu thuật.

\section{KẾT QUẢ}

Có 22 bệnh nhân đạt tiêu chuẩn nghiên cứu, tuổi trung bình 45,3 $\pm 13,1(23-68)$, nam giới chiếm $68,2 \%$. Nguyên nhân chấn thương ngực kín do tai nan giao thông chiếm tới $72,7 \%$. Dấu hiệu cơ năng chủ đạo là đau ngực và khó thở (100\%). Các dấu hiệu thực thể nặng có tỷ lệ khá cao, như mảng sườn di động thể bên 40,9\% (9 ca), biến dạng lồng ngực 54,5\% (12 ca) [Biểu đồ 1]. Chấn thương ngực kín đơn thuần gặp ở 7 bệnh nhân $(31,8 \%)$. Các tổn thương phối hợp rất đa dạng, trong đó hay gặp nhất là gãy xương chi $54,5 \%$ (12 ca). Chẩn đoán xác định thể bệnh chấn thương ngực kín trước mổ KHXS gồm: $100 \%$ có tràn máu - tràn khí màng phổi, có tổn thương đụng dập phổi / chụp cắt lớp vi tính (CLVT) ở 12 ca $(54,5 \%), 1$ ca ổ cặn màng phổi chấn thương.

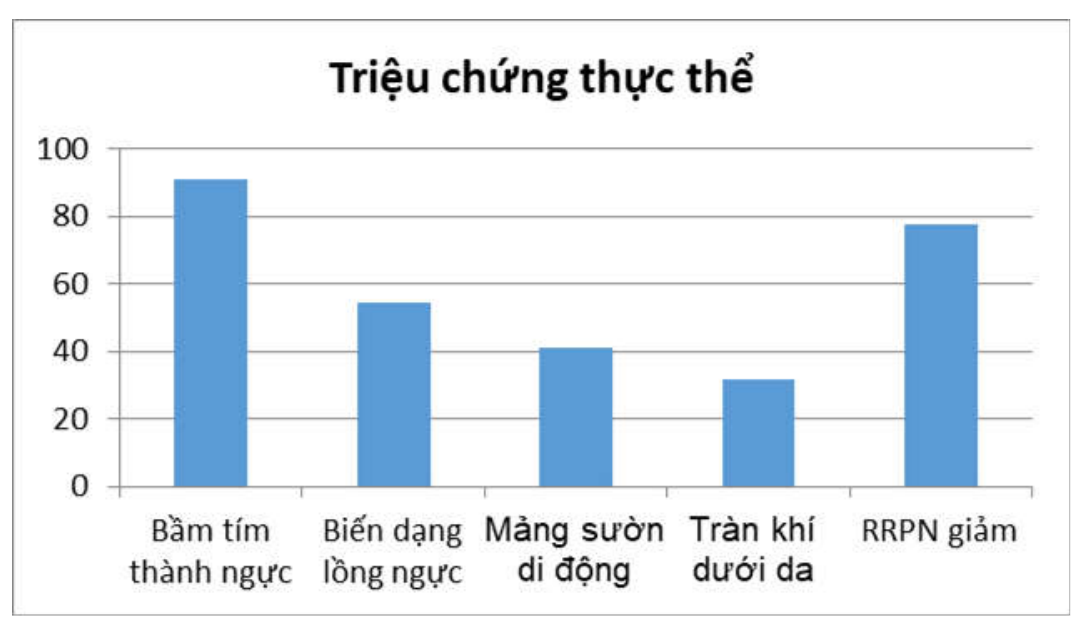

Biểu đồ 1: Triệu chứng thực thể của chấn thưong ngực trước mổ KHXS

Số lượng vị trí xương sườn gãy phát hiện được trên chụp CLVT là $8,86 \pm 3,53$ xương / 1 bệnh nhân (6 - 19), cao hơn một cách có ý nghĩa $(\mathrm{p}<0,05)$ so với phim $\mathrm{X}$ quang ngực thẳng thông thường là $6,86 \pm 3,70$ xương / 1 bệnh nhân $(5-$
18). Khả năng phát hiện gãy xương sườn của $X$ quang ngực kém hơn so với chụp CLVT đối với các xương sườn ở cao và thấp, nhưng vẫn rất hiệu quả đối với các xương sườn 4-6 (biểu đồ 2). Chỉ số tính điểm xương sườn gãy (Rib fracture score 
- RFS)[1] được tính theo công thức: "RFS = (số điểm xương sườn gãy $\mathrm{x}$ số bên gãy) + yếu tố tuổi”; trong đó, số điểm xương sườn gãy được hiểu là số các ổ gãy xương sườn, trên một cung xương sườn có thể có nhiều vị trí gãy khác nhau, đặc biệt trong mảng sườn di động; yếu tố tuổi già ảnh hưởng đến tỷ lệ biến chứng và tử vong trong bệnh lý gãy xương sườn (Hình 1). Theo đó, chỉ định KHXS hầu hết dành cho đối tượng có RFS mức độ 3-4 (Bảng 1).

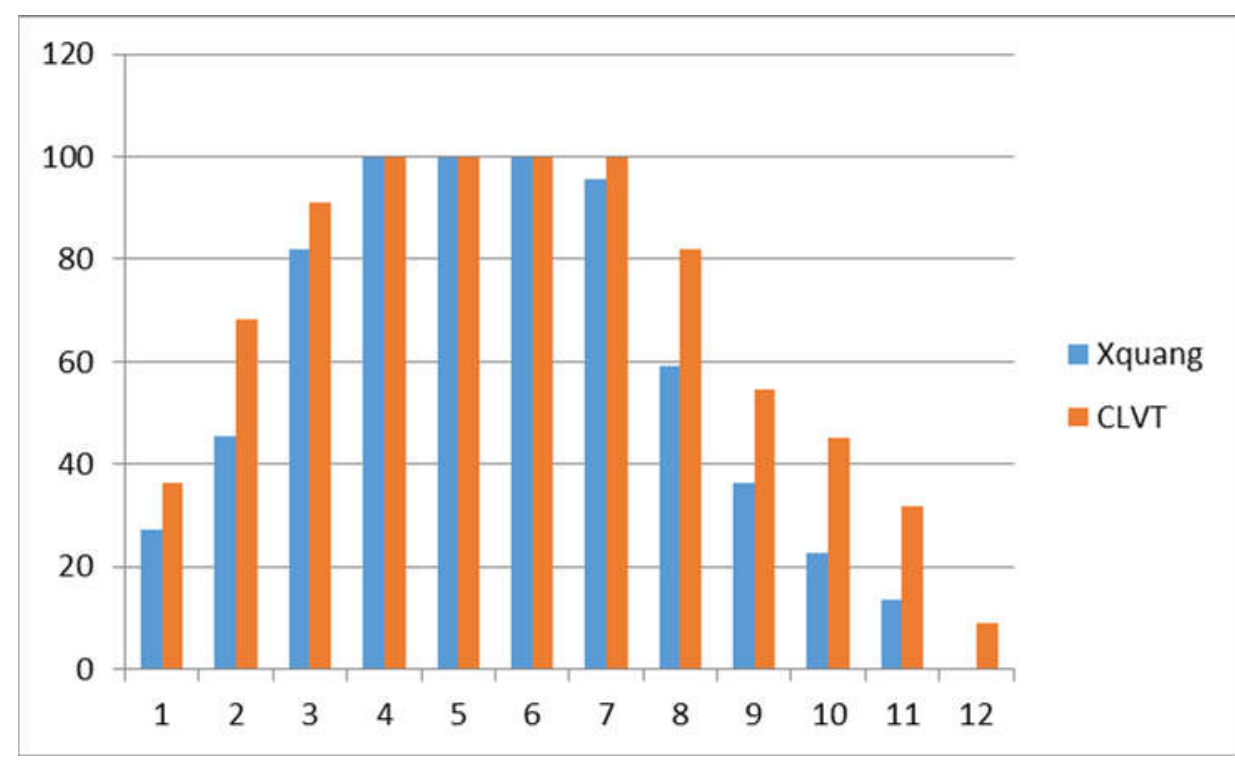

Biểu đồ 2: Phân bố vị trí xuơng suờn gãy (1-12) theo X quang và Cắt lớp vi tính (CLVT)

Bảng 1: Phân bố theo điểm gãy xuơng suờn (RFS)

\begin{tabular}{|l|l|c|}
\hline \multicolumn{1}{|c|}{ Mức độ } & \multicolumn{1}{|c|}{ Khuyến cáo điều trị theo May L. [1] } & $\begin{array}{c}\text { Số lượng (\%) } \\
\text { (n=22) }\end{array}$ \\
\hline 1 (RFS từ 3-6 điểm) & Giảm đau thông thường. & $0(0 \%)$ \\
\hline 2 (RFS từ 7-10 điểm) & Giảm đau phối hợp thông thường và morphin. & $1(4,5 \%)$ \\
\hline 3 (RFS từ 11-15 điểm) & $\begin{array}{l}\text { Giảm đau morphin tĩnh mạch liên tục phối hợp } \\
\text { giảm đau thần kinh. }\end{array}$ & $4(18,2 \%)$ \\
\hline 4 (RFS >15 điểm) & $\begin{array}{l}\text { - Giảm đau bằng đặt catheter phong bế cơ răng } \\
\text { trước hoặc cạnh sống. } \\
\text { - Phẫu thuật cố định xương sườn. }\end{array}$ & $17(77,3 \%)$ \\
\hline
\end{tabular}

Thời gian phẫu thuật KHXS trung bình là $98,5 \pm 12,5$ phút $(82-130)$. Số lượng xương được kết hợp trung bình là $3,1 \pm 1,03$ xương; hầu hết bệnh nhân được kết hợp 3 xương sườn $(63,6 \%)$, nhiều nhất là 6 xương cho bệnh nhân bị gãy 19 xương. Vị trí xương hay được kết hợp nhất là xương sườn 4 - 7 tại vị trí cung bên, trong đó có $100 \%$ ở xương sườn 5 và $81,8 \%$ ở xương sườn 6 . Không có các biến chứng đáng kể nào trong khi mổ. Sau mổ các bệnh nhân đều được điều trị giảm đau toàn thân bằng paracetamol, trong đó có $2 \mathrm{ca}(9,1 \%)$ cần kết hợp thêm bằng giảm đau vùng (giảm đau cạnh sống hoặc ngoài màng cứng). Kết quả chung sau mổ ở bảng 2 , trong đó khỏi không có biến chứng ở 19 bệnh nhân $(86,4 \%), 2$ ca xẹp phổi và 1 ca viêm phổi / tổn thương phối hợp nặng (chấn thương động mạch cánh tay đầu) và điều trị hồi sức 3 ngày với thời gian nằm viện 25 ngày. Không có trường hợp nào tử vong trong nhóm nghiên cứu. 
Bảng 2: Kết quả chung sau mổ KHXS

\begin{tabular}{|l|c|c|c|}
\hline \multicolumn{1}{|c|}{ Thò̀i gian (ngày) } & Trung bình & Ngắn nhất & Dài nhất \\
\hline Thời gian nằm hồi sức & $1,17 \pm 0,65$ & 0 & 3 \\
\hline Thời gian rút dẫn lưu màng phổi & $5,2 \pm 1,7$ & 3 & 12 \\
\hline Thời gian nằm viện* & $12,2 \pm 4,9$ & 8 & 25 \\
\hline
\end{tabular}

* Tính đến thời điểm bệnh nhân hoàn toàn ổn định về lồng ngực.

\section{BÀN LUẬN}

Phẫu thuật KHXS đã được thực hiện trong nhiều thập kỷ gần đây. Nhờ những cải tiến về trang thiêt bị, dụng cụ, điều trị chống nhiễm khuẩn...; mà tới nay phẫu thuật KHXS đã chứng minh được hiệu quả trong điề̀ trị và mang lại nhiều lợi ích rõ rệt ở nhóm các bệnh nhân có tổn thương ngực nặng phải thở máy, mảng sườn di động, nhờ giúp sớm định hình lại khung lồng ngực, phục hồi chức năng phổi và giảm đau. Ngoài ra, phẫu thuật KHXS cũng được chỉ định trong các trường hợp đau do gãy xương sườn - không đáp ứng với kiểm soát đau thông thường, gãy xương sườn dị lệch nhiều và khi có phẫu thuật lồng ngực phối hợp [1],[5],[6],[7]. Tuy nhiên, do KHXS là một can thiệp có chi phí lớn hơn nhiều so với điểu trị bảo tồn kinh điển, nên hiện nay trên thế giới vẫn chưa có đồng thuận chung về chỉ định KHXS. Có một số quan điểm, song 2 chỉ định phổ biến nhất là theo Marc de Moya (2017) [7] và May L (2015) [1].
So sánh với chỉ định của May L (Hình 1) [1], chỉ định theo Marc de Moya (Hình 2) [7] chủ yêu phụ thuộc theo số xương sườn gãy và độ tuổi bệnh nhân. Số lượng xương sườn gãy liên quan trực tiếp tới tình trạng nặng của chấn thương, cũng như tiên lượng tỷ lệ biến chứng và tử vong có thể xảy ra với người bệnh. Theo đó, trong nghiên cứu có $77,3 \%$ bệnh nhân đáp ứng chỉ định kết hợp xương sườn, với chỉ số xương sườn gãy $(\mathrm{RFS})>15$ điểm, còn lại 5 bệnh nhân (chiếm 22,7\%) có RFS dưới 15 điểm. Tuy nhiên 5 bệnh nhân này đều đáp ứng kém với điều trị giảm đau bằng morphin (sau 3 ngày sử dụng giảm đau tích cực vẫn không hiệu quả), đặt ra vấn đề cần kết hợp xương sườn. Ngoài ra, chỉ định của May L còn bộc lộ một số hạn chế khi chỉ định phẫu thuật chỉ căn cứ vào số xương sườn gãy và độ tuổi bệnh nhân, mà hoàn toàn bỏ qua triệu chứng cơ năng và thực thể như biến dạng lồng ngực, mảng sườn di động...; chính những cải tiến trong chỉ định của Marc de Moya đưa ra đã khắc phục được những hạn chế này, nên nhanh chóng được áp dụng phổ biến hơn trong chỉ định phẫu thuật KHXS.

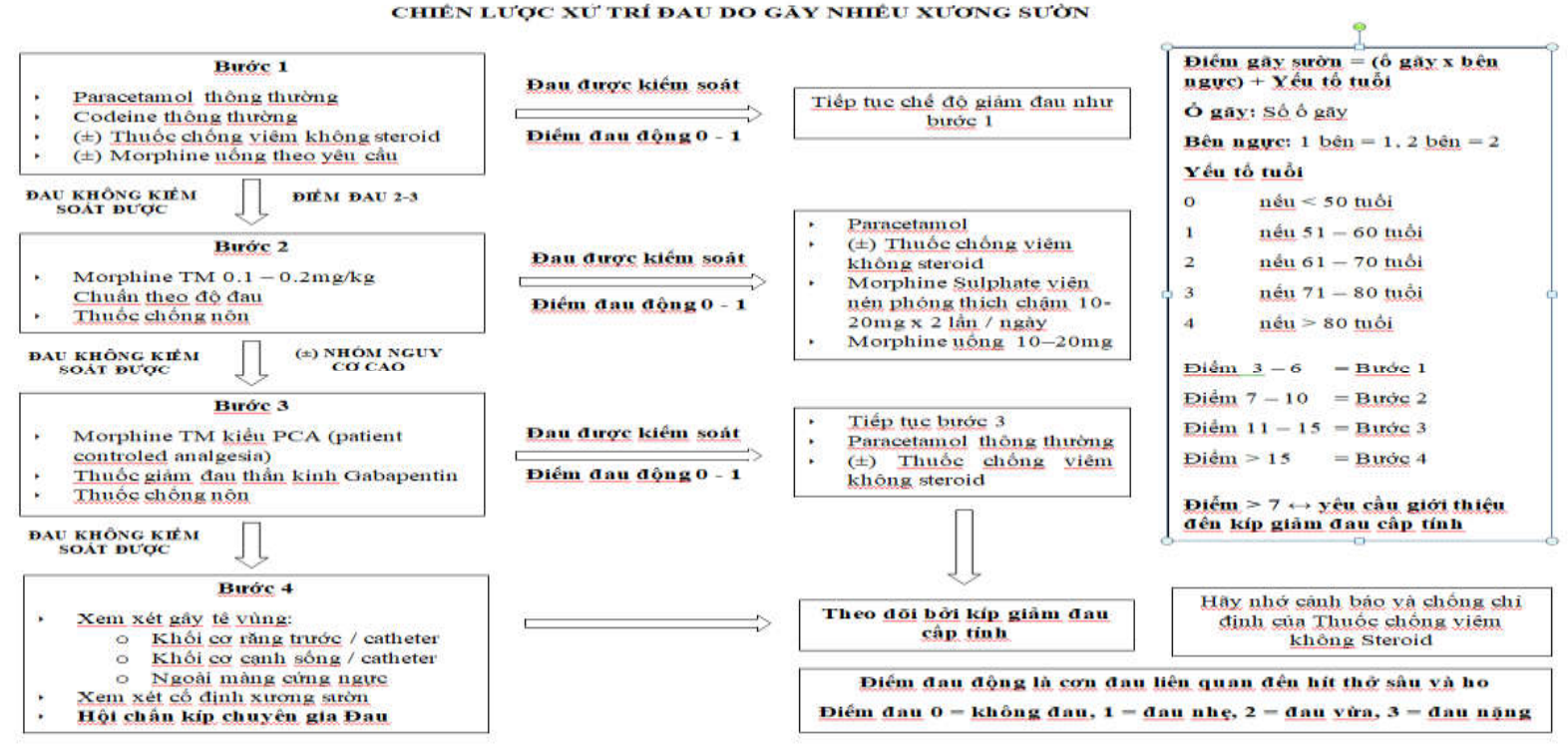

Hình 1: Chiến lược điều trị gãy nhiều xuoong sườn (dịch theo May L 2015) [1] 
Dựa theo chỉ định của Marc de Moya (2017) [7], 100\% bệnh nhân của nghiên cứu đã đáp ứng hoàn toàn chỉ định này: $100 \%$ có gãy từ 6 xương sườn dị lệch trở lên, cá biệt có một bệnh nhân gãy tối đa 19 xương sườn; 40,9\% bệnh nhân có mảng sườn di động; $54,5 \%$ bệnh nhân có biến dạng lồng ngực; và một trường hợp có gãy xương sườn kết hợp với ổ cặn màng phổi chấn thương - được kết hợp xương sườn và sử lý làm sạch khoang màng phổi cùng một thì. Không có bệnh nhân nào có chống chỉ định phẫu thuật KHXS (Hình 2). Theo kết quả nghiên cứu, chúng tôi thấy rằng chỉ định của Marc de Moya (2017) giúp thực hiện chỉ định được dễ dàng và phân loại điều trị bệnh nhân một cách hiệu quả hơn, cũng như đưa ra những chống chỉ định cụ thể cho phẫu thuật KHXS.

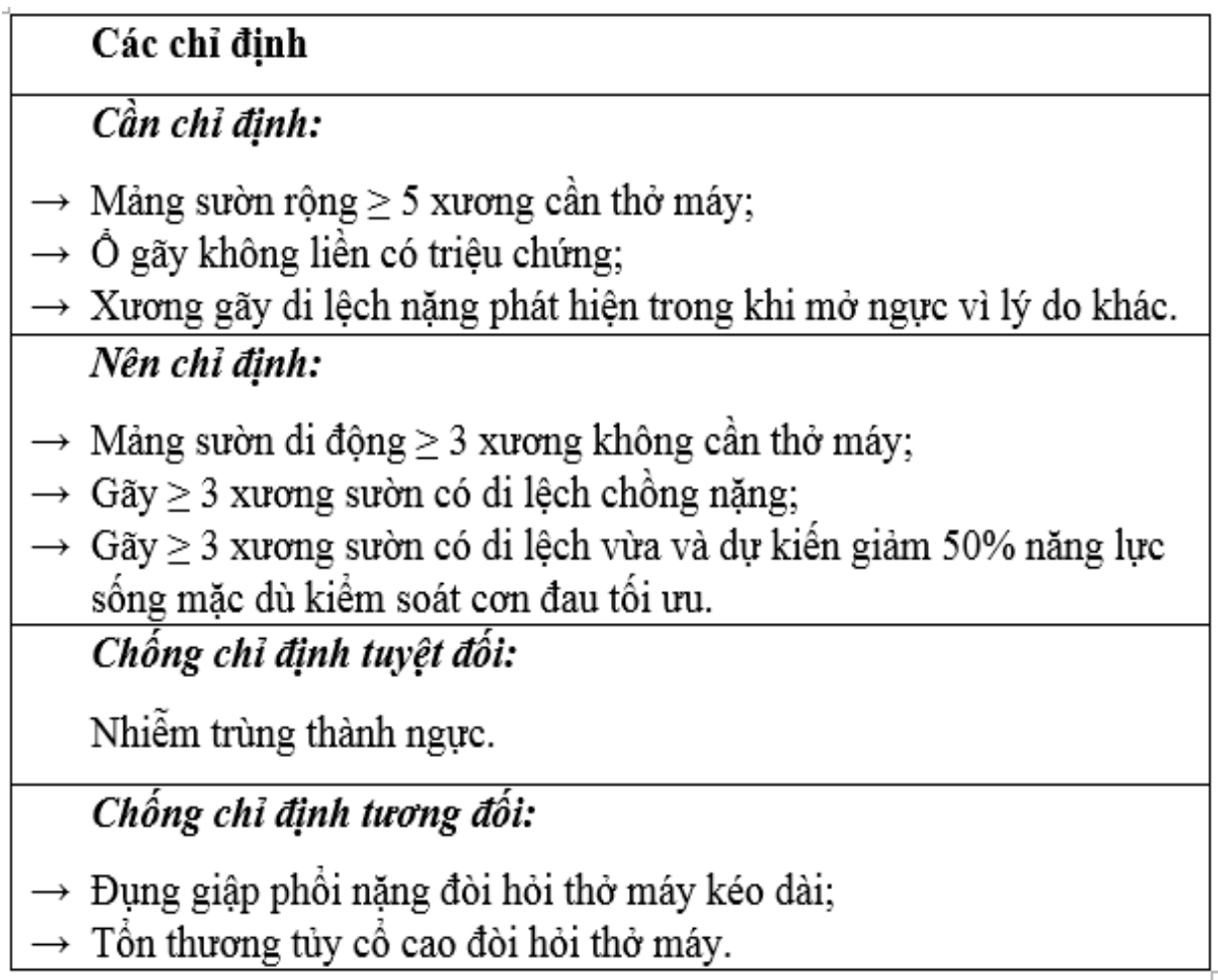

Hình 2: Chỉ định kết hợp xuoong suờn (dịch theo Marc de Moya 2017) [7]

Về phương pháp phẫu thuật, nhóm nghiên cứu sử dụng đường rạch ngang tại vị trí tương ứng với ổ gãy xương sườn, mở dọc theo thớ cơ không cắt cơ, bộc lộ xương sườn, đặt nẹp và KHXS bằng nẹp vít RibFixBlu. Loại nẹp sử dụng là nẹp 8 lỗ với vít tự khóa, nẹp được định hình sẵn cong theo chiều cong của xương sườn, và có thể sử dụng uốn để phù hợp hơn cho từng bệnh nhân. Trung bình số xương sườn gãy được kêt hợp xương là $3,1 \pm 1,03$ xương, và chủ yếu kết hợp tại vị trí cung bên xương sườn. Điều này cũng tương tự với các nghiên cứu khác như của
Kocher GJ và cộng sự nghiên cứu ở 105 bệnh nhân KHX sườn năm 2016, số lượng xương sườn kết hợp trung bình là $4,5 \pm 1,8$ xương [6], vị trí chủ yếu là cung bên và sử dụng nẹp 8 lỗ ở mỗi vị trí gãy. Tương tự, nghiên cứu của Campbell N năm 2009 ở 32 bệnh nhân với số lượng kêt hợp xương trung bình là 3 xương [8]. Vị trí kết hợp xương sườn cũng rất quan trọng, theo nghiên cứu của Cameron Gettel năm 2014, KHXS chỉ nên thực hiện từ xương sườn thứ 3 đến thứ 10 , đặc biệt là xương sườn 5 - được coi là chìa khóa để giải quyết tình trạng mảng sườn 
di động cũng như mất ổn định của lồng ngực; còn xương sườn 1,2 và 11,12 có vai trò không lớn trong việc đảm bảo chức năng hô hấp của lồng ngực; vị trí được kết hợp nhiều nhất cũng là cung bên xương sườn từ 3 đến 6 [9]. Kết quả này cũng giống như trong nghiên cứu của chúng tôi khi vị trí xương hay được kết hợp nhất là xương sườn 4-7 tại vị trí cung bên, trong đó $100 \%$ xương sườn 5 được kết hợp, $81,8 \%$ bệnh nhân được kết hợp xương sườn 6 .

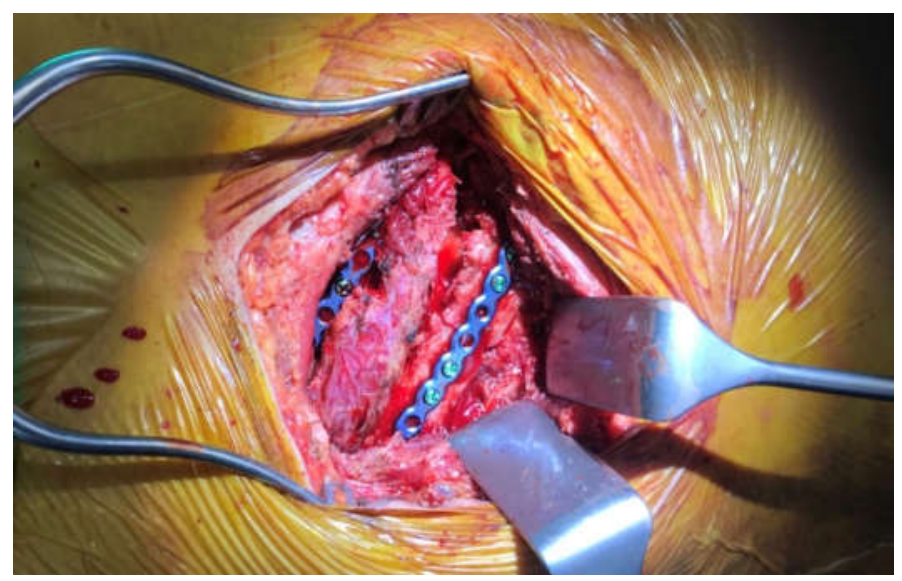

Hình 3: Kết hợp xuơng suờn bằng tấm nẹp vit [nguồn: tác giả]

Bảng 3: So sánh kết quả phẫu thuật và hậu phẫu giũa các nghiên cưu

\begin{tabular}{|c|c|c|c|c|c|}
\hline \multicolumn{2}{|c|}{ Chỉ số } & $\begin{array}{c}\text { Chúng tôi } \\
(n=22)\end{array}$ & $\begin{array}{l}\text { Kocher GJ } \\
{[6] \quad(n=102)}\end{array}$ & $\begin{array}{c}\text { Althausen PL } \\
{[3](n=22)}\end{array}$ & $\begin{array}{c}\text { Marasco SF } \\
{[4](n=23)}\end{array}$ \\
\hline \multicolumn{2}{|c|}{ Thời gian mổ trung bình (phút) } & $98,5 \pm 12,5$ & - & 55 & - \\
\hline \multirow{2}{*}{\multicolumn{2}{|c|}{$\begin{array}{l}\text { Số xương sườn kết hợp (cái) } \\
\text { Thời gian nằm hồi sức (ngày) }\end{array}$}} & $3,1 \pm 1,03$ & $4,5 \pm 1,8$ & - & - \\
\hline & & $1,17 \pm 0,65$ & $4,5 \pm 5,02$ & 2,68 & 11,8 \\
\hline \multicolumn{2}{|c|}{ Thời gian nằm viện (ngày) } & $12,2 \pm 4,9$ & $9,54 \pm 7,12$ & $11,9 \pm 7,79$ & 20,0 \\
\hline \multirow{4}{*}{$\begin{array}{l}\text { Biến } \\
\text { chứng } \\
\text { (n/\%) }\end{array}$} & Không & $19(86,4 \%)$ & $96(94,1 \%)$ & - & - \\
\hline & Suy hô hấp & 0 & $1(1,6 \%)$ & - & - \\
\hline & Xẹp phổi & $2(9,1 \%)$ & 0 & - & - \\
\hline & Viêm phổi & $1(4,55 \%)$ & $5(8,2 \%)$ & $1(4,55 \%)$ & $11(47,83 \%)$ \\
\hline \multicolumn{2}{|c|}{ Tỷ lệ tử vong } & $0 \%$ & $4,9 \%$ & $0 \%$ & $0 \%$ \\
\hline
\end{tabular}

Thời gian mổ trung bình trong nghiên cứu là $98,5 \pm 12,5$ phút, ngắn nhất là 80 phút, dài nhất là 130 phút. Thời gian này có dài hơn so với công bố của Althausen năm 2014 [3], nguyên nhân do kỹ thuật KHXS mới được triển khai tại Trung tâm Tim mạch và Lồng ngực, kinh nghiệm của phẫu thuật viên còn hạn chế và thiếu một số trang thiết bị phục vụ quá trình phẫu thuật. Dù vậy, thời gian nằm hồi sức sau mổ của bệnh nhân chúng tôi lại ngắn nhất, là $1,17 \pm 0,65$ ngày, so với 2,68 ngày theo nghiên cứu của Althausen và 4,5-11,8 ngày theo công bố của các tác giả khác (Bảng 3). Đây là một trong những ưu điểm nổi trội của phẫu thuật KHXS đáng được ghi nhận so với phương pháp điều trị bảo tồn. Cũng theo những nghiên cứu trên, KHXS mang lại hiệu quả rõ rệt khi giảm thời gian thở máy, thời gian điều trị hồi sức sau mổ cũng như các biến chứng liên quan đến hô hấp [4],[5],[8]. Thời gian nằm viện trong nghiên cứu của chúng tôi là $12,2 \pm 4,9$ ngày, cũng tương tự với các nghiên cứu khác, và không có tử vong trong giai đoạn hậu phẫu. Trong nghiên cứu của 
Kocher GJ, 3 trong số 102 bệnh nhân có 5 ca tử vong $(4,9 \%)$, nhưng đều do biến chứng nặng của các tổn thương phổi hợp khác [6]. Biến chứng gặp ở 3 trường hợp gồm 2 bệnh nhân có xẹp phổi và 1 bệnh nhân viêm phổi đều được điều trị nội khoa tích cực, lý liệu pháp hô hấp và soi hút khí phế quản ở bệnh nhân xẹp phổi, không có trường hợp nào phải mổ lại. Theo Leinicke JA [10], đánh giá tổng quan về điều trị phẫu thuật KHXS thông qua hơn 1400 nghiên cứu đã cho thấy rõ ràng hiệu quả của phương pháp, gồm: giảm thời gian nằm thở máy, thời gian nằm hồi sức, giảm thời gian nằm viện cũng như giảm các biến chứng viêm phổi và tỷ lệ tử vong của nhóm phẫu thuật khi so sánh với nhóm điều trị bảo tồn [10].

\section{KẾT LUẬN}

Phẫu thuật KHXS bằng tấm nẹp vít để điều trị gãy xương sườn là phẫu thuật mới áp dụng tại Trung tâm Tim mạch và Lồng ngực, bệnh viện Hữu nghị Việt Đức. Chỉ định phẫu thuật được chọn lựa cẩn thận và đảm bảo tính hợp lý dựa trên triệu chứng lâm sàng và cận lâm sàng. Phẫu thuật KHXS đã chứng minh được hiệu quả điều trị, mang lại tính an toàn, cải thiện chất lượng cuộc sống cho bệnh nhân. Từ những thành công bước đầu này, phẫu thuật KHXS bằng tấm nẹp vít hiện đã được áp dụng một cách thường quy tại bệnh viện Hữu nghị Việt Đức và được đang đánh giá sâu hơn thông qua các đề tài nghiên cứu khác, đặc biệt cần so sánh với nhóm điều trị bảo tồn, cũng như đánh giá hiệu quả lâu dài của phẫu thuật.

\section{TÀI LIÊU THAM KHẢO}

1. May L, Hillermann C, Patil S. Rib fracture management. BJA Education. 2015;16(1):26-32.

2. Vyhnánek F, Jirava D, Očadlík M, Škrabalová D. Surgical Stabilisation of Flail Chest Injury: Indications, Technique and Results. Acta chirurgiae orthopaedicae et traumatologiae Cechoslovaca. 2015;82(4):303-307.
3. Althausen PL, Shannon S, Watts C, et al. Early surgical stabilization of flail chest with locked plate fixation. Journal of orthopaedic trauma. Nov 2011;25(11):641-647.

4. Marasco SF, Davies AR, Cooper J, et al. Prospective randomized controlled trial of operative rib fixation in traumatic flail chest. Journal of the American College of Surgeons. May 2013;216(5):924-932.

5. Caragounis EC, Fagevik Olsén M, Pazooki D, Granhed H. Surgical treatment of multiple rib fractures and flail chest in trauma: a one-year follow-up study. World journal of emergency surgery : WJES. 2016;11:27.

6. Kocher GJ, Sharafi S, Azenha LF, Schmid RA. Chest wall stabilization in ventilatordependent traumatic flail chest patients: who benefits?. European journal of cardio-thoracic surgery : official journal of the European Association for Cardio-thoracic Surgery. Apr 1 2017;51(4):696-701.

7. De Moya M, Nirula R, Biffl W. Rib fixation: Who, What, When?. Trauma surgery \& acute care open. 2017;2(1):e000059.

8. Campbell N, Conaglen P, Martin K, Antippa P. Surgical stabilization of rib fractures using Inion OTPS wraps--techniques and quality of life follow-up. The Journal of trauma. Sep 2009;67(3):596-601.

9. Cameron Gettel DM. Rib Fracture Repair: Assessing the Effects of Various Levels of Fixation on Stability of a Flail Chest Segment. AMSRJ. 2014;1.

10. Leinicke JA, Elmore L, Freeman BD, Colditz GA. Operative management of rib fractures in the setting of flail chest: a systematic review and meta-analysis. Annals of surgery. Dec 2013;258(6):914-921. 